\title{
Symultaniczna aktywność przedstawicieli nauki, biznesu i samorządów czynnikiem dynamizującym kreatywność
}

\section{The simultaneous activity of the representatives of science, business and local governments as a factor stimulating creativity}

\section{Streszczenie}

Trzy czynniki warunkujące dynamikę postępu: nauka, samorząd, biznes mają historię sięgającą starożytności. Trudno będzie w tej triadzie pojęć wybrać dziedzinę najważniejszą bądź też pierwotną, aczkolwiek w kolejności z racji jej korzeni należałoby wymienić kreatywność człowieka. Ta cecha implikuje rozwój przedsiębiorczości, rodzaj aktywności wiodącej do rozwoju cywilizacyjnego. Człowiek dąży do zaspokojenia hedonistycznych pragnień, pragnienia stymulują wynalazczość, a ta przyczynia się do zwiększania produkcji i wykorzystania jej w celach utylitarnych. Zatem łańcuch przyczynowo-skutkowy jest nieskończony. Dynamiczna efektywność współpracy zależy w dużej mierze od jej symultaniczności.

Słowa kluczowe: samorząd, biznes, nauka, aktywność, kreatywność, współpraca, symultaniczny

\section{Abstract}

In our deliberations on the main topic we should emphasize the relationship between the three titular factors determining the dynamics of progress: science, local government and business. They all have a history dating back to antiquity. It will be difficult to select the most important or the original field in this triad of concepts, but due to its roots we should mention human creativity. This feature implies the development of entrepreneurship, the type of activity that leads towards civilizational development. Thanks to technological progress, also towards satisfying the hedonistic desires and its use for utilitarian purposes. Thus, the cause and effect chain is infinite. The dynamic efficiency of cooperation largely depends on its simultaneity.

Keywords: local government, business, science, activity, creativity, collaboration, simultaneous 
Zakładając, że to człowiek jest stymulatorem wszelkich działań nie tylko na poziomie jednostki, co wynika z charakteru społecznego istoty ludzkiej, to w triadzie: nauka, samorząd, biznes, to ON jest najistotniejszym ogniwem aktywności poszczególnych jej składników. W historii społeczeństw istotnym czynnikiem czy też systemem, otwierającym drogę do współdziałania w obrębie grup społecznych, była i jest niewątpliwie demokracja, której zawiła historia roi się nie tylko od wątków pozytywnych, ale również dramatycznych i brutalizujących, gdyż dzieląc się swoimi myślami, może oczekiwać lepszych efektów od społeczeństwa, wiodących ku wojnie i wyginięciu kultur. System demokratyczny jest systemem, który działa na zasadzie podejmowania decyzji przy współudziale grup społecznych, działających w zróżnicowanym zasięgu terytorialnym, począwszy od jednostek gminnych, powiatowych, wojewódzkie aż po krajowe. Człowiek jako istota społeczna szuka współuczestników działań, dąży do współpracy z innymi członkami grupy. W społeczeństwie demokratycznym istotnym warunkiem rozwoju pozytywnego, a więc pokojowego danego terytorium jest umiejętność osiągnięcia konsensusu, który powinien skutkować ogólnie pojętym postępem dla dobra każdej grupy - od najmniejszej do niemal globalnej.

Geneza samorządu terytorialnego i jego rola w rozwoju społeczeństw jest dziedziną zbadaną przez ekonomistów. Bardzo interesująco pisze o tym problemie Adam Szewczuk - Rozwój lokalny na tle współczesnych uwarunkowań - rekomendacje dla praktyki samorzq̨dowej ${ }^{1}$. Zeszyty Naukowe WSB w Poznaniu przedstawiają obszerny materiał dotyczący całego spektrum zagadnień związanych z zajmującym nas tematem. Genezę samorządów lokalnych w ujęciu historycznym można znaleźć w pracy Z. Niewiadomskiego Geneza samorzqdu lokalnego ${ }^{2}$.

Nauka - samorząd - biznes, trudno w tej triadzie wybrać dziedzinę najważniejszą bądź też pierwotną, aczkolwiek w kolejności z racji jej korzeni należałoby wymienić najpierw kreatywność człowieka jako istoty najbardziej aktywnej.

Homo sapiens charakteryzuje się oprócz rozumności i zdolności do życia w społeczeństwie cechą, którą nie mogą poszczycić się inne gatunki: kreatywnością w niezliczonych dziedzinach.

Ta cecha implikuje również rozwój przedsiębiorczości, rodzaju aktywności prowadzącej człowieka do dobrobytu oraz rozwoju cywilizacyjnego, postępu technicznego, a więc ku wiedzy i wykorzystaniu jej w celach utylitarnych. Zatem łańcuch przyczynowo skutkowy jest nieskończony.

Wartościowanie poszczególnych dziedzin nie powinno hamować żadnej z nich, a więc jedynym rozwiązaniem jest dialog, gdyż wszystkie te trzy dziedziny stymulują się nawzajem. We współczesnym świecie system wzajemnych powiązań między poszczególnymi dziedzinami, pozornie nie mającymi ze sobą ścisłych związków, jawi się jako rodzaj tkanki, w której każde ogniwo jest związane z całością. Można to zjawisko porównać do organizmu, w którym wszystkie elementy współpracują ze sobą z pożytkiem dla całości. Jeżeli jeden z elementów nie działa sprawnie, całość zaczyna podupadać. Można zatem wysnuć prosty 
wniosek - współpraca poszczególnych składników całości warunkuje zrównoważony rozwój pozbawiony luk, czyli strat. Tak więc, aby ta machina nabrała przyspieszenia i eksplodowała tempem rozwoju dającym wszystkim satysfakcję, jej poszczególne tryby muszą być ze sobą połączone. Jeżeli naukowiec będzie siedział w gabinecie i kreował kolejne teorie, przekuwając je na wiedzę teoretyczną, przewagę nad nim będzie miał tryb empiryczny, piękny umysł straci kontakt z rzeczywistością, ale jeśli ta rzeczywistość go odkryje i wciągnie w swoje tryby, bez szkody dla jego umysłu pojawią się efekty wymierne i pożyteczne dla ludzi, dla społeczeństwa. Można wymienić wiele czynników warunkujących postęp w dziedzinie gospodarczej na danym obszarze:

- nauka a praktyka,

- związki między funkcjami samorządu terytorialnego a uczelnią,

- efektywność gospodarcza,

- dialog między przedstawicielami odmiennych dziedzin,

- zdolność przekonywania w obopólnym interesie.

\section{Nauka a praktyka}

Już na etapie edukacji akademickiej należy nauczyć studenta umiejętności wdrażania wiedzy w praktyce. Do tego nie wystarczą pracownie i warsztaty na terenie wyższej szkoły, konieczny jest natomiast kontakt z profesjonalistami w danej dziedzinie, działającymi poza uczelnią, między innymi we wszystkich jednostkach samorządów terytorialnych, w zakładach produkcyjnych i innych wyspecjalizowanych miejscach. Tu można podkreślić istotę funkcji mistrza i ucznia. Ten tradycyjny duet przyczynił się do powstania całych pokoleń mistrzów. Kiedyś zarówno uczeń, jak i mistrz zajmowali się znacznie węższym spektrum zadań do rozwiązania, zazwyczaj jedną specjalnością. Dziś konstrukcja świata jest znacznie bardziej złożona, zatem i system edukacji akademickiej ma wielowarstwową materię, wymagającą kompleksowej wiedzy oraz kontaktu studenta z doświadczonym praktykiem, który ponad wszelką wątpliwość poszerza jego świadomość w zakresie zawodu do którego się przygotowuje.

\section{Związki między samorządem terytorialnym a uczelnią}

Konieczność nawiązania kontaktu między samorządem a uczelnią umożliwia nawiązanie dialogu dotyczącego potrzeb obydwu stron i metod spełnienia wzajemnych oczekiwań.

\section{Efektywność gospodarcza}

Warunkiem efektywności gospodarczej w całej triadzie jest konieczność procesu nieustającego uaktualniania wiedzy i zastosowania nowych technik, które przyspieszają powstawanie efektów ekonomicznych przy najwyższej jakości powstających produktów. Zatem korzyści są obopólne! 


\section{Dialog między przedstawicielami odmiennych dziedzin}

Dialog jest koniecznością i wieńczy poszukiwania kolejnych wartości, o które jest wzbogacana wiedza obydwu stron.

\section{Zdolność przekonywania w obopólnym interesie}

Pod tym hasłem ukrywa się niewątpliwie sztuka negocjacji w celu uzyskania efektu zadowalającego obydwie strony.

\section{Uczelnia kuźnią wiedzy}

Aby osiągnąć efektywność gospodarczą, konieczna jest wysoka jakość kształcenia, uwzględniająca wagę potrzeb szeroko pojętego rynku oraz konieczność komunikacji między podmiotami gospodarczymi a uczelnią.

Warunkiem jest współpraca z podmiotami gospodarczymi, nawiązanie dialogu, badanie sytuacji, począwszy od lokalnych małych przedsiębiorstw w gminach. Doniosła jest również rola wiedzy o potrzebach społeczeństwa, a także współpraca w zakresie innowacyjności. Procesy wiodące do lepszych efektów gospodarczych, a zatem i ekonomicznych, wynikają z jednoczesnej komunikacji badawczej między nauką, samorządem i biznesem. Nauka jako jeden ze składników potrzebuje jednak wsparcia.

\section{Kuźnie wiedzy}

Uczelnie muszą być wyposażone w narzędzia wspomagające ich rozwój - laboratoria, warsztaty i inne narzędzia badawcze. Konkurencyjność między uczelniami implikuje walkę o środki finansowe. Tutaj wsparcie biznesu jest nieodzowne. Duże przedsiębiorstwa, mające dobre wyniki ekonomiczne, chętnie współpracują z uczelniami, przyciągają do siebie dobrze wykształconą kadrę, której wiedza może podnieść efektywność dużych i małych przedsiębiorstw produkcyjnych, zaspokajających potrzeby rynku, a zatem i społeczeństwa. Współfinansowanie uczelni podnosi jej status, a uczelnia z kolei musi przekonać inwestujące w nią podmioty gospodarcze o swojej aktywności w dziedzinie nauki, prowadzącą do innowacyjności i w konsekwencji polepszenia efektywności działalności gospodarczej, przekładającej się na jakość życia grup społecznych w małych i dużych skupiskach ludzkich. Na końcu tego łańcucha jest cały naród.

\section{Warunki współpracy}

W społeczeństwie, mającym intencję rozwojową, można wymienić kilka czynników warunkujących sukces, w tym umiejętność nawiązania dialogu poznawczego.

\section{Dialog - komunikacja}

Aby ten warunek został spełniony, musi istnieć badanie lokalnych aktywności, czyli poszukiwanie. W tym celu istotną rolę odgrywa informacja połączona z dociekliwością badacza i wyznaczaniem sobie celów. 
W tej dziedzinie warunkiem poszerzenia pola informacji między poszczególnymi obszarami aktywności jest stworzenie odpowiednich ścieżek między szkołą wyższą, samorządem i biznesem. W takim procesie konieczna jest jednoczesność aktywności wszystkich trzech elementów.

Ogromne znaczenie ma w tym procesie edukacja na poziomie uczelni i uświadamianie młodemu pokoleniu zasadności nawiązywania kontaktów z samorządami i biznesem. Te ostatnie z konieczności w fazie inwestycji nawiązują kontakty. Na tym polu rola uczelni wyższych jest niedoceniona. Młodzież jest głodna wiedzy, ale poza obowiązkowym akademickim kształceniem nie posiada wystarczających wiadomości o roli, jaką odgrywają w rozwoju gospodarczym pozostałe dwie dziedziny. Wiedza na temat pożyteczności wymiany wzajemnej całego spektrum informacji, popartej doświadczeniem działalności gospodarczej, jest nieodzowna w procesie zrównoważonego rozwoju wszystkich dziedzin.

Do tego właśnie powinny służyć owe ścieżki, które wiodą młode pokolenia do świata biznesu i gospodarki terytorialnej, a więc do gmin, powiatów, sołectw.

Inicjatywy takich kontaktów często rodzą się na uczelniach. Kontakty między elementami triady uczelnia - samorząd - biznes stymulują aktywność na wszystkich trzech poziomach, ale najistotniejszym efektem jest edukacja młodzieży w oparciu o zdobycze i doświadczenia pozostałych dwóch elementów. Istnieje konieczność komunikacji między samorządem, biznesem i uczelnią oraz czerpanie z niej wiedzy, pomagającej osiągnąć pełną efektywność w danym zawodzie.

\section{Nauka a praktyka}

Kontakt studenta z doświadczonym przedstawicielem zawodu bądź też grupami zawodowymi, mogącymi podjąć współpracę z uczelnią już na etapie kształcenia akademickiego, jest nieodzownym elementem, mającym pozytywny wpływ na jakość kształcenia. Dzięki temu absolwent jest lepiej przygotowany do pracy w terenie. $W$ tym celu organizowane są warsztaty dla studentów, aktywujące współpracę z samorządami w miastach, gminach, a nawet sołectwach, jeśli w danej dziedzinie zaistnieje taka potrzeba.

Przykładem takiej praktyki w przypadku Wydziału Architektury może być połączenie warsztatów twórczych - zajęć plenerowych z czerpaniem wiedzy w zakresie wielu zagadnień związanych z architekturą i urbanistyką. Tak więc student ma możliwość zapoznać się z pracą i kompetencjami urzędu miasta, gminy, gospodarki leśnej, lokalnym przemysłem i innowacyjnością ludzi na wszystkich szczeblach gospodarki, a zatem i z biznesem. Opiekun danej grupy pomaga przyszłym architektom wytyczyć ścieżki, które ułatwią ogarnąć sieć powiązań między elementami gospodarki w terenie.

Warsztaty w Starym Sączu w maju 2017 roku, trwające 5 dni, pozwoliły na zrealizowanie założonego programu, w którym uczestniczyło 11 studentów z drugiego roku studiów magisterskich oraz jeden opiekun - dr hab. Iwona Zuziak, prof. PK. Program obejmował studiowanie piękna miasta Stary Sącz, którego efektem są prace rysunkowe, malarskie i fotograficzne. Ponadto odbyły się spotkania z przedstawicielami lokalnego samorządu oraz biznesu. 
W związku z bogatym programem pobytu organizator zadbał również o spotkanie z ludźmi kultury. Tutaj warto przytoczyć komentarz studentki Agaty Kujdy ze spotkania z prof. Andrzejem Szarkiem: „Dnia 22.04.2017 zostaliśmy zaproszeni do odwiedzenia Galerii Sokół w Nowym Sączu, gdzie powitała nas bardzo ciepło Pani Ewa Rams, specjalista do spraw organizacji wystaw. Zostaliśmy zachęceni do zapoznania się z niedawno otwartą wystawą SuperSam, poruszającą zjawisko wielowymiarowej samotności człowieka we współczesnym świecie” oraz: „(...) zarysowuje problematykę, że sztuka współczesna nie musi być przede wszystkim atrakcyjna jak towar w supermarkecie. Może ukazywać wartości, które sprawiają, że człowiek przestaje być sam i staje się towarzyszem prawdy, dobra i piękna".

W tym kontekście po obejrzeniu prac takich artystów, jak Henryk Cześnik, Jacek Jagielski, Jacek Waltoś czy Krystyna Pasterczyk, podjęliśmy rozważania na temat istoty talentu-artyzmu, a tym samym istoty bycia artystą. Dyskusję na ten temat podjął z nami prof. Andrzej Szarek, artysta rzeźbiarz, wykładowca i szef Rady Programowej Galerii BWA Sokół. Przedstawił on nam swoją filozofię wyboru dzieł na wystawę, u której podstaw leży jakość pracy, a nie jego komercyjna wartość rynkowa. Dlatego też wśród artystów znajdują się także mniej znani lub dopiero rozpoczynający karierę malarze czy rzeźbiarze.

Według kuratora współczesny rynek walczy z prawdziwą sztuką i talentem, sprowadzając ją do roli produktu i kształtując na zasadzie popyt - podaż. Dlatego w tym kontekście talent to nie jeden przymiotnik opisujący artystę, ale zbiór cech. Andrzej Szarek talent porównuje do dłoni, która składa się z pięciu palców, a każdy z nich jest niezbędny do tworzenia całości pojęcia. Podobnie jest z talentem który tak jak dłoń posiada 5 składowych, do których należą: umiejętność, wrażliwość, charakter, świadomość i pożądliwość. Charakter i świadomość to dwie cechy, nad którymi się pracuje, gdyż stanowią narzędzie do opanowania pożądliwości i wrażliwości. Umiejętność natomiast jest wrodzona lub kształtowana. Nie ma jednak mocy i siły bez czterech pozostałych. W rozmowie doszliśmy do wniosku, że brak któregokolwiek ze składników upośledza twórcę, a samo pojęcie talentu nie oznacza wrodzonej zdolności i „geniuszu”. Padło wiele pytań i bardzo ciekawych uwag zarówno z naszej strony, jak i samych pracowników galerii. Rozmowa była bardzo poruszająca i dająca nam powód do późniejszych rozważań i dyskusji we wspólnym gronie. Po wizycie otrzymaliśmy także pamiątkowe katalogi z wystawy".

Celowo cytuję notatkę studentki ze spotkania w obiekcie kultury, ponieważ oprócz doniosłości jej samej, należy podkreślić, iż ta dziedzina jest również elementem ściśle związanym z samorządem terytorialnym, biznesem, a także jest niezwykle ważnym czynnikiem edukacji społeczeństwa! Po wizycie w Galerii Sokół grupa studentów udała się na spotkanie z burmistrzem Starego Sącza, Jackiem Lelkiem. Burmistrz w swojej prezentacji przybliżył grupie zasady gospodarowania przestrzenią tego pięknego miasta, dużą część wykładu poświęcając planom inwestycyjnym, ilustrowanym bardzo nowoczesnymi odważnymi inwestycjami, wpisanymi w historyczną tkankę miasta. To wzbudziło duże zainteresowanie wśród młodzieży. 
W programie warsztatów odbyło się także spotkanie z architektem Michałem Jasiewiczem, nowosądeczaninem, który prezentując własne malarstwo akwarelowe, poza uwagami warsztatowymi, podkreślił rolę postrzegania piękna architektury i przyrody w drodze zawodowej architekta. Kolejnym mistrzem był architekt Paweł Kurzeja, prowadzący firmę projektową, który przekazał studentom wiedzę o warsztacie pracy architekta, między innym zaznaczając istotę sztuki negocjacji z inwestorem. Następnie przedstawił własne szkice do projektów, będące świadectwem słuszności posiadania umiejętności operowania językiem plastycznym w komunikacji z inwestorami.

Nadleśniczy Paweł Szczygieł przedstawił nam niezwykle cenną prezentację na temat roli ochrony zasobów zielonych, współpracy z gminami oraz nasadzania zieleni w przestrzeniach publicznych. Dzięki uprzejmości nadleśniczego grupa biorąca udział w warsztatach mogła uczestniczyć w objeździe samochodami terenowym i wysłuchać wykładów towarzyszących leśników. Wizyta w nadleśnictwie uzmysłowiła studentom architektury, jak ciężką i ważną pracę wykonują ludzie lasu, począwszy od gajowego do nadleśniczego.

Wizyta w gminie Łabowa, spotkanie z wójtem Markiem Janczakiem, jego wykład na temat strategii działania samorządu lokalnego w celu zrównoważonego rozwoju gminy oraz wykorzystania jej zasobów naturalnych, dokumentacja prototypu samochodu napędzanego energią słoneczną oraz repliki czołgu zwiadowczego - tankietki z II wojny światowej (obydwa obiekty zbudowane przez wójta gminy Łabowa).

Wizyta w Firmie Drewpol, spotkanie z właścicielem - mistrzem stolarstwa Wojciechem Szczygłem, zwiedzanie hal produkcyjnych, zapoznanie się z technologicznym procesem produkcji z drewna, prezentacja wykonanych obiektów architektonicznych, detali oraz wnętrz z wykorzystaniem różnych gatunków drewna, prezentacja samochodu zbudowanego przez wójta gminy Łabowa z karoserią drewnianą wykonaną przez Wojciecha Szczygła, wykorzystanie materiałów naturalnych w projektowaniu, rola ekologii w przyszłym kreowaniu przestrzeni.

Należy podkreślić ważną rolę studiów malarskich i rysunkowych z natury w rozwijaniu edukacyjnej roli architekta w społeczeństwie. Istotna jest twórczość w wielu dziedzinach: architektura, malarstwo, rzemiosło artystyczne, gdyż to te dziedziny wspomagają edukację społeczeństwa dzięki kontaktowi ze sztuką.

Konkluzja z powyższych przemyśleń, popartych praktycznymi przykładami, wiedzie do wskazania drogi, jaką powinny zmierzać wszystkie trzy składniki owej wspomnianej na początku triady: nauka, samorząd, biznes. Inicjatorem kontaktu z pozostałymi powinien być każdy ze składników, bo tylko partnerstwo na tej scenie prowadzi do słusznej stymulacji aktywności w sferze wzajemnych powiązań prowadzących do sukcesu! 

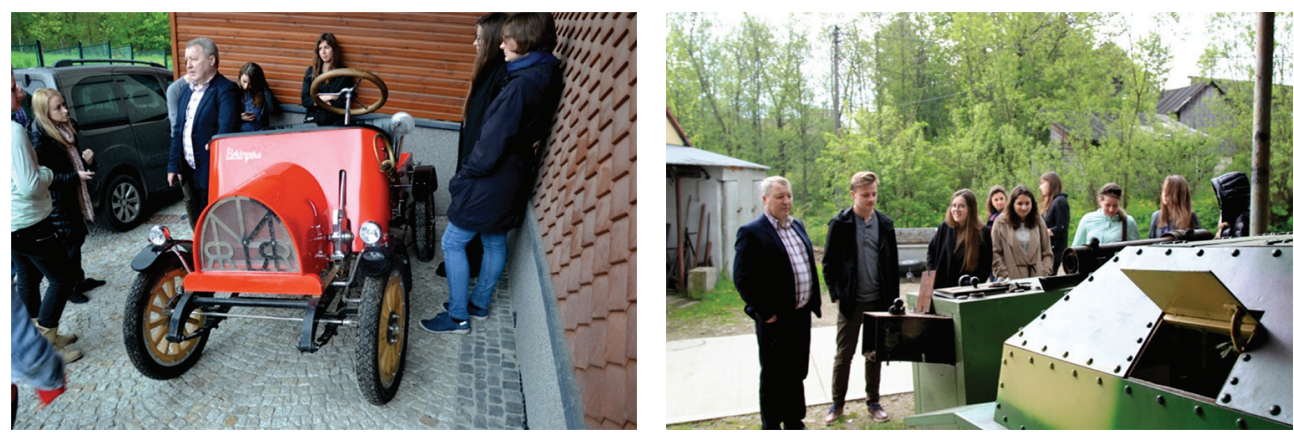

II. 1-2. Od lewej: Wójt gminy Łabowa Marek Janczak prezentuje studentom wykonany przez siebie samochód (pojazd napędzany energią słoneczną) oraz replikę tankietki z II wojny światowej również swojego autorstwa

III. 1-2. From the left: Mayor of Łabowa Municipality Marek Janczak is presenting a self-made car (a solar-powered vehicle) and a self-made replica of the World War II tankette to the students
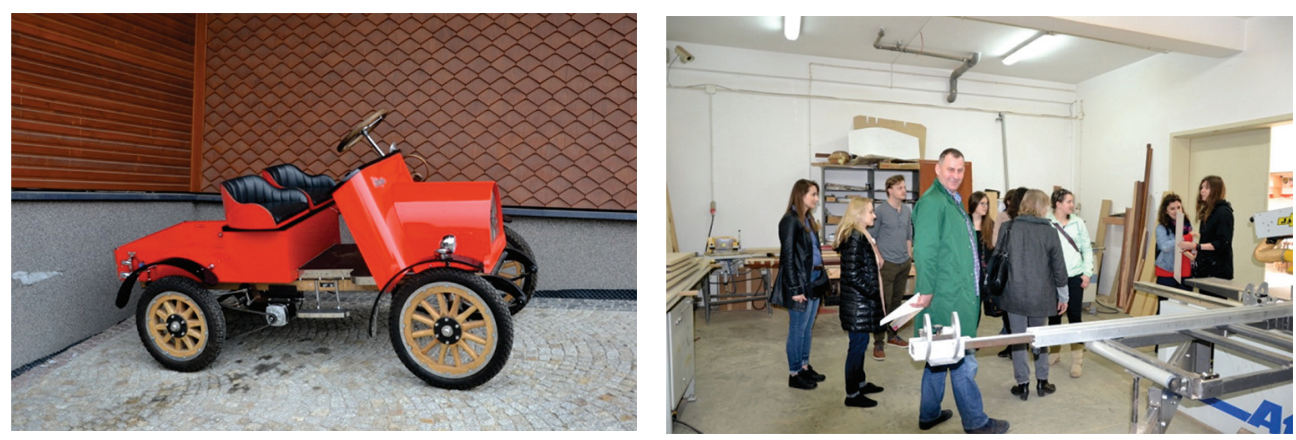

II. 3-4. Od lewej: samochód, do którego karoserię oraz drewniane koła wykonał mistrz stolarski Wojciech Szczygieł, właściciel firmy Drewpol; Wojciech Szczygieł oprowadza studentów po zakładzie produkcyjnym II. 3-4. From the left: the car whose body and wooden wheels were made by carpenter Wojciech Szczygiet, the owner of Drewpol; Wojciech Szczygieł is walking the students around the production plant 

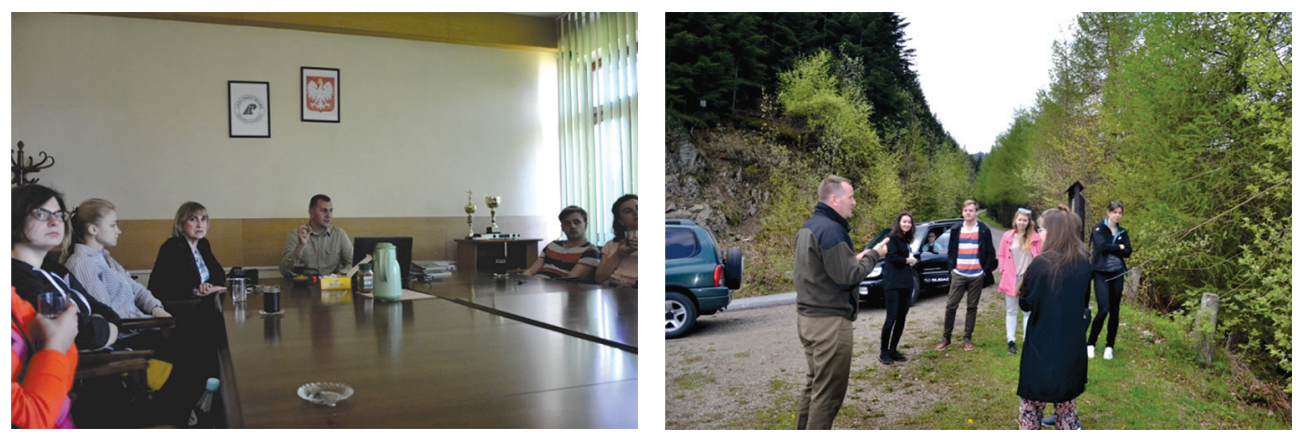

II. 5-6. Od lewej: Nadleśniczy Paweł Szczygieł prezentuje osiągnięcia regionu leśnego położonego w województwie małopolskim, w powiecie nowosądeckim i limanowskim; studenci słuchają wykładu

Pawła Szczygła w terenie na Przehybie

III. 5-6. From the left: Forest Inspector Paweł Szczygieł presents the achievements of the forest region located in Małopolska Voivodeship, in Nowy Sącz and Limanowa districts; the students are listening to the lecture by Paweł Szczygła in the area of Przehyba Mountain
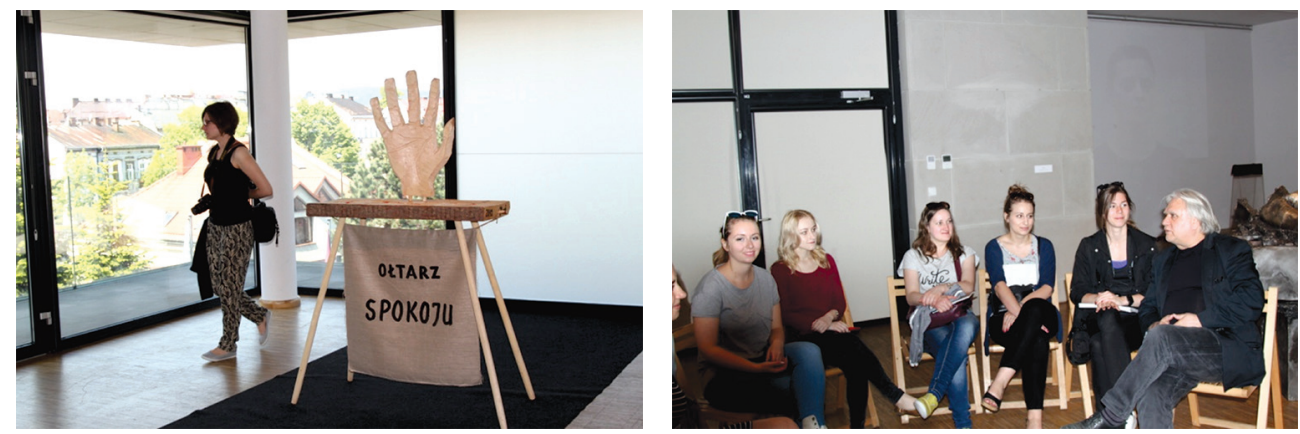

II. 7-8. Od lewej: rzeźba Jerzego Beresia; profesor Andrzej Szarek rozmawia ze studentami architektury o sztuce

III. 7-8. From the left: the sculpture by Jerzy Bereś; Professor Andrzej Szarek is talking to the architecture students about art

II. 9. Pokaz nowych wozów strażackich na Rynku Starego Sącza

III. 9. The exhibition of new fire trucks at Stary Sącz Square

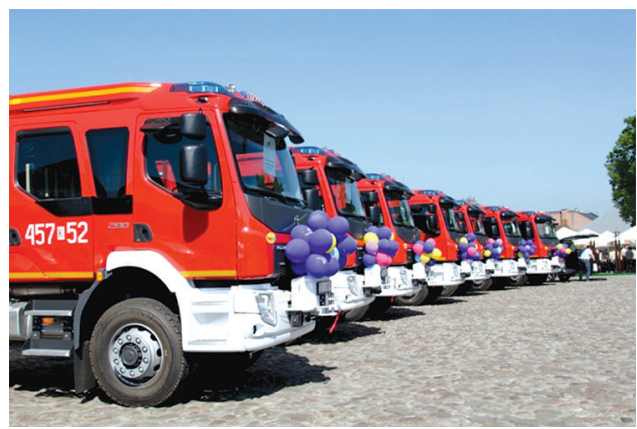


PRZYPISY

1 A. Szewczuk, Triada zależności przyczynowo-skutkowych: rozwój lokalny i regionalny - nowe zarzq̨dzanie publiczne - partycypacja obywatelska, „Zeszyty Naukowe Wyższej Szkoły Bankowej w Poznaniu", Nr 31/2010, s. 83.

2 Z. Niewiadomski, Geneza samorzqdu terytorialnego, [w:] Słownik samorzqdu terytorialnego, (red.) M. Chmaj, Lublin 1997.

\section{BIBLIOGRAFIA}

Aronson E., Wilson T.D., Akert R., Psychologia społeczna, Zysk i s-ka, Poznań 2012.

Kozłowski S., Upodmiotowienie samorzqdu lokalnego w okresie transformacji systemowej w Polsce, Elipsa, Warszawa 2015.

Izdebski H., Samorzqd terytorialny - podstawy ustroju i działalności, LexisNexis, Warszawa 2014. 